\title{
The role of environmental and occupational exposures in Turkish immigrants with fibre-related disease
}

\author{
P. Dumortier*, A. Göcmen*, K. Laurent", A. Manço", P. De Vuyst*
}

The role of environmental and occupational exposures in Turkish immigrants with fibrerelated disease. P. Dumortier, A.Göcmen, K. Laurent, A. Manço, P. De Vuyst. (C)ERS Journals Ltd 2001.

ABSTRACT: Environmental exposure to tremolite and erionite causes endemic diseases of the lung and pleura in Turkey. This study aimed to evaluate the impact of these exposures and further occupational exposures on fibre-related diseases in Turkish immigrants living in Belgium.

The study included 51 males and 17 females that emigrated $<1-38$ yrs ago. Most of them $(n=46)$ had nonmalignant pleural lesions, one had asbestosis and one had mesothelioma. Environmental asbestos exposure was likely for the majority of patients $(60 \%)$, but there were also reports of possible occupational asbestos $(n=14)$ and erionite $(n=2)$ exposure.

Tremolite was the main fibre type in bronchoalveolar lavage fluid (BALF). Elevated concentrations of amosite or crocidolite were detected in only two patients. The delay elapsed since the end of the environmental exposure had no influence on the asbestos body or the tremolite fibre concentrations in the BALF of Turkish immigrants.

Most fibre-related diseases in Turkish immigrants are probably due to environmental rather than occupational exposure. Precise information about geographical origin and occupation should be obtained when investigating these patients. Mineralogical analysis of bronchoalveolar lavage fluid gives valuable information on the type and intensity of exposure, especially in patients with both environmental and occupational exposure. Eur Respir J 2001; 17: 922-927.
*Chest Dept, Hôpital Erasme, Université Libre de Bruxelles, Brussels,

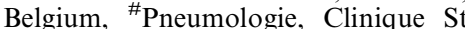
Etienne, Brussels, Belgium and Institut de Recherche, Formation et Action sur les Migrations, Belgrade, Belgium.

Correspondence: P. Dumortier, Chest Dept, CUB Hôpital Erasme, Route de Lennik 808, B1070 Brussels, Belgium. Fax: 3225554255

\section{Keywords: Asbestos bronchoalveolar lavage electron microscopy environmental exposure tremolite Turkey}

\section{Received: August 252000}

Accepted after revision January 26 2001

This work was supported in part by grant no. 3.4524.97 from the Fonds de la Recherche Scientifique Médicale.
In rural areas of Turkey, tremolite fibres in soils or rocks, and their local use for whitewashing houses and various other purposes [1], cause high outdoor and indoor airborne fibre concentrations responsible for endemic lung and pleural diseases. These environmental or domestic exposures occur $24 \mathrm{~h} \cdot \mathrm{day}^{-1}$, begin at birth and last the entire life, unless the individual moves to an area without such exposure. All types of asbestos-related diseases have been associated with these exposures [1-3] and the prevalence of exposures and diseases are similar for males and females [2]. As in industrial settings, nonmalignant pleural disease is the most frequent finding. The prevalence of pleural calcifications in tremolite-exposed populations increases with age and may reach $>50 \%$ in those $>60 \mathrm{yrs}$ of age [2]. An annual incidence of mesothelioma of around 50 per million has been reported in asbestos-exposed districts of South-East Turkey [2]. A survey focussing on a more restricted area and population reported a much higher incidence [4]. Very high annual incidences of mesothelioma, from 2,200 to 8,000 cases per million, are related to environmental exposure to erionite, a fibrous zeolite formed during hydrothermal alteration of volcanic ashes in several villages near Urgup in Cappadocia [1].

Several millions of individuals live in areas with the aforementioned environmental exposures. Cases of "imported" asbestos diseases resulting from environmental exposure during youth at birthplace have been reported in Western Europe and North America among immigrants from endemic areas of Turkey [5-8], Corsica [9] and Afghanistan [10]. In all of them, the relationship between the environmental origin of exposure and the disease was ascertained by elevated concentrations of tremolite fibres in biological samples. An epidemic of malignant mesothelioma in a cohort of immigrants from Karain, an erionite village, has also been reported in Sweden [11].

According to the authors' experience, fibre-related chest diseases are common among Turkish immigrants in Belgium. Some of them have worked in occupations with possible exposure to asbestos. This study aimed to evaluate the relative contribution of the original environmental exposure, and of possible further occupational exposures in Turkish immigrants with asbestos-related disease.

\section{Materials and methods}

The study population included all 68 Turkish immigrants who were identified from $>5,000$ subjects 
whose bronchoalveolar lavage fluid (BALF) had been referred, on clinical indication, for a mineralogical analysis to the authors' laboratory since 1979. Mineralogical analyses were requested as part of the medical evaluation. Routine demographic and exposure data collected for each patient included age, sex, province and town or village of origin in Turkey, date of emigration, and occupation(s) (table 1). The probability of domestic asbestos exposure (use of whitewash) was also recorded. The main source of data was the original request for BALF analysis complemented by contacts with the referring chest physician. Whenever possible, patients $(n=32)$ were interviewed in their native language by a chest physician who was familiar with the problems of asbestos exposure in Turkey.

The population was classified into six subgroups according to the likelihood of environmental and occupational exposure to asbestos (table 2). The probability of environmental exposure was classified as probable or unlikely on the basis of the maps published by BARIs [1] and DUMORTIER et al. [12], and information on the geology of Turkey. The probability of occupational asbestos exposure was classified

Table 1.-Demographic and clinical data

\begin{tabular}{|c|c|}
\hline \multicolumn{2}{|l|}{ Age at sampling yrs } \\
\hline Mean (SD) & $51(11)$ \\
\hline Range & $24-78$ \\
\hline $20-35$ & 4 \\
\hline $36-55$ & 37 \\
\hline 56 & 25 \\
\hline Unknown & 2 \\
\hline \multicolumn{2}{|l|}{ Gender $\mathrm{n}$} \\
\hline Males & 51 \\
\hline Females & 17 \\
\hline \multicolumn{2}{|l|}{ Duration of stay in Turkey yrs } \\
\hline Mean (SD) & $28(12)$ \\
\hline Range & $5-78$ \\
\hline \multicolumn{2}{|l|}{ Delay since leaving Turkey yrs } \\
\hline Mean (SD) & $23(8)$ \\
\hline Range & $<1-38$ \\
\hline \multicolumn{2}{|l|}{ Disease males/females* } \\
\hline Bilateral benign pleural disease & $34 / 12$ \\
\hline Malignant mesothelioma & $1 / 0$ \\
\hline Lung fibrosis & $1 / 0$ \\
\hline Lung cancer & $3 / 2$ \\
\hline Pleural effusion & $5 / 0$ \\
\hline Other ${ }^{\#}$ & $10 / 2$ \\
\hline No abnormalities & $2 / 1$ \\
\hline Unknown & $6 / 1$ \\
\hline \multicolumn{2}{|l|}{ Main occupation $n$} \\
\hline Housewife & 17 \\
\hline White-collar & 2 \\
\hline Blue-collar & 46 \\
\hline Unskilled construction worker & 22 \\
\hline Coal miner & 7 \\
\hline Insulation worker & 5 \\
\hline Steel and metal workers & 6 \\
\hline Other & 6 \\
\hline Unknown & 3 \\
\hline
\end{tabular}

*: Some patients had more than one disease; ${ }^{*}$ : emphysema $(\mathrm{n}=1)$, bronchiectasis $(\mathrm{n}=1)$, broncholithiasis $(\mathrm{n}=1)$, pneumonia $(n=1)$, coal worker's pneumoconiosis $(n=2)$, nonspecific abnormalities at computed tomography (e.g. ground glass opacities: $n=6$ ).
Table 2.-Definition of exposure groups and number of cases in each one

\begin{tabular}{lr} 
Type of exposure & Cases n \\
\hline Very likely environmental asbestos exposure. & 30 \\
$\quad$ Occupational exposure unlikely. & \\
Unlikely environmental or occupational & 9 \\
$\quad$ exposure. & 11 \\
Mixed exposure (environmental and & \\
$\quad$ occupational) likely. & 3 \\
Only occupational exposure. & 2 \\
Exposure to erionite in Tuzkoy. & 13 \\
Unknown because of unavailable data about & \\
$\quad$ geographical origin or occupation. &
\end{tabular}

according to the description of the patient's working life [13].

From 4-70 mL (mean \pm SD $27 \pm 11 \mathrm{~mL}$ ) of BALF from the 2nd and/or 3rd fractions were used for mineralogical analysis. Preparation of BALF and determination of asbestos body (AB) and uncovered fibres (UF) $>10 \mu \mathrm{m}$ by light microscopy and of the total fibre burden by electron microscopy have been extensively described previously [12]. Analytical sensitivities were usually $<0.1 \mathrm{AB} \cdot \mathrm{mL}^{-1}$ or $\mathrm{UF} \cdot \mathrm{mL}^{-1}$ of BALF for light microscopy and $<50$ fibres $(>1 \mu \mathrm{m}) \cdot \mathrm{mL}^{-1}$ of BALF for electron microscopy. Results from the present study were compared to those of patients still living in Turkey (residents) [12].

Age, duration and delay since end of exposure are reported as mean $\pm S D$. Since these variables were not normally distributed among immigrants and residents, they were compared using the Kolmogorov-Smirnov test. $\mathrm{AB}$ and fibre concentrations, and dimensions (width, length and aspect ratio) are reported as geometric mean (geometric standard deviation; 95\% confidence interval) (GM (GSD; 95\% CI)). Depending on the number of groups to be compared, MannWhitney U- or Kruskal-Wallis tests were used.

\section{Results}

The number of patients in each exposure group is reported in table 2. Among those interviewed, 18 of 32 $(56 \%)$ remembered participating in whitewashing or had lived in whitewashed houses. Housewives and bluecollar workers represent $25 \%$ and $68 \%$ of the subjects, respectively. The latter were mainly occupied as unskilled construction workers, but some of them were coal miners, painters, steel workers or insulators (table 1). The three cases with only occupational exposure had worked as a railroad worker, an asbestos removal worker and a grinder in steelworks.

Lesions compatible with an asbestos-related disease were present in most of the study subjects. Nonmalignant pleural lesions were predominant (table 1) and were seen in $86 \%$ of the subjects with environmental asbestos exposure only, in $100 \%$ of those with mixed environmental and occupational exposure, and in $22 \%$ of those with unlikely exposure. There was one case of mesothelioma and one case of lung fibrosis among the subjects with environmental exposure. Lung cancers 
Table 3. - Asbestos body and fibre concentrations by light microscopy in bronchoalveolar lavage fluid (BALF) of Turkish immigrants according to exposure group

\begin{tabular}{|c|c|c|c|c|}
\hline & Tremolite exposure & Mixed exposure & Unknown exposure & Unlikely exposure \\
\hline $\begin{array}{l}\text { Percentage of BALF } \\
\text { with } \geqslant 1 \mathrm{AB}^{\mathrm{B}} \cdot \mathrm{mL}^{-1} \text { and/or } \\
\quad \geqslant 3 \mathrm{UF} \cdot \mathrm{mL}^{-1} \mathrm{BALF}\end{array}$ & 77 & 91 & 54 & 11 \\
\hline $\mathrm{AB} \cdot \mathrm{mL}^{-1} \mathrm{BALF}$ & $\begin{array}{c}5.9(6.4 ; 2.3-12) \\
\text { ND-1530 }\end{array}$ & $\begin{array}{c}19(10 ; 3.2-92) \\
\text { ND-1000 }\end{array}$ & $\begin{array}{c}1.2(2.2 ; 0.4-2.5) \\
\text { ND-13 }\end{array}$ & $\begin{array}{c}0.36(1.3 ; 0.2-0.7) \\
\text { ND-1 }\end{array}$ \\
\hline $\mathrm{UF} \cdot \mathrm{mL}^{-1} \mathrm{BALF}$ & $\begin{array}{c}4.4(5.2 ; 1.9-9) \\
\text { ND-444 }\end{array}$ & $\begin{array}{c}15(12 ; 2.1-84) \\
\text { ND-2119 }\end{array}$ & $\begin{array}{c}2.5(3.4 ; 0.7-6.3) \\
\text { ND-57 }\end{array}$ & $\begin{array}{c}0.22(1.3 ; 0.01-0.5) \\
\text { ND }-1\end{array}$ \\
\hline
\end{tabular}

Data presented as geometric mean (geometric standard deviation; 95\% confidence interval) with the range indicated below unless otherwise stated. AB: asbestos body; UF: uncovered fibre longer than $10 \mu \mathrm{m}$; ND: not detected.

Table 4. - Fibre concentrations (in fibres $\cdot \mathrm{mL}^{-1}$ ) by electron microscopy in bronchoalveolar lavage fluid (BALF) of Turkish immigrants with environmental exposure to tremolite, mixed occupational and environmental exposure and without asbestos exposure

\begin{tabular}{|c|c|c|c|c|}
\hline & Tremolite & Chrysotile & Amosite-crocidolite & Nonasbestos fibres \\
\hline \multirow{2}{*}{$\begin{array}{l}\text { Tremolite exposure } \\
\quad(\mathrm{n}=20)\end{array}$} & $195(11 ; 63-398)$ & $1.7(8.1 ; 0-6)$ & $0.6(4.0 ; 0-2)$ & $19(18 ; 4-75)$ \\
\hline & ND-7933 & ND-864 & ND-169 & ND-1778 \\
\hline \multirow{2}{*}{$\begin{array}{l}\text { Mixed exposure } \\
\quad(\mathrm{n}=10)\end{array}$} & $162(46 ; 10-2510)$ & $5.5(7.2 ; 0.6-26)$ & $3.7(14 ; 0-30)$ & $33(23 ; 3-315)$ \\
\hline & ND-39278 & ND-49 & ND-1009 & ND-1556 \\
\hline \multirow{2}{*}{$\begin{array}{l}\text { No fibre exposure } \\
(\mathrm{n}=5)\end{array}$} & $5.0(12 ; 0-125)$ & ND & $1.4(7.2 ; 0-27)$ & $105(14 ; 3-2875)$ \\
\hline & ND-93 & & ND-81 & ND-549 \\
\hline
\end{tabular}

Data presented as geometric mean (geometric standard deviation; 95\% confidence interval) with the range indicated below. ND: not detected.

were reported for one male without asbestos exposure, for two females and one male with environmental exposure, and for one male with mixed exposure. Benign pleural lesions were present in these last four subjects.

When all groups were taken together, there were $>1 \mathrm{AB} \cdot \mathrm{mL}^{-1}$ and/or $>3 \mathrm{UF} \cdot \mathrm{mL}^{-1}$ of BALF in $64 \%$ of the subjects. The highest $\mathrm{AB}$ counts were detected in those with environmental or mixed asbestos exposures (table 3 ). Concentrations $>1 \mathrm{AB} \cdot \mathrm{mL}^{-1}$ and $>3 \mathrm{UF} \cdot \mathrm{mL}^{-1}$ were seen in $73 \%$ and $40 \%$ of the subjects with environmental exposure, respectively, and $82 \%$ and $63 \%$ of those with mixed exposure, respectively. $\mathrm{AB}$ (or ferruginous body (FB)) concentrations were 98, 22 , and $0.12 \mathrm{AB} \cdot \mathrm{mL}^{-1}$ in the three patients with only occupational exposure, and 1.8 and $0.9 \mathrm{FB} \cdot \mathrm{mL}^{-1}$ in the two patients with exposure to erionite.

The chemical composition of the core fibre of 293 ABs from 25 patients was analysed. Tremolite was identified in $95 \%$ of the bodies from those with environmental exposure and $69 \%$ from those with mixed exposure. Among those with environmental exposure, all the bodies not built on tremolite (crocidolite $(\mathrm{n}=3)$, anthophyllite $(\mathrm{n}=1)$ and chrysotile $(\mathrm{n}=1))$ were identified in the same patient. Four patients from seven with mixed exposure had bodies on other types of asbestos, mainly amosite. FBs mimicking typical ABs were detected in patients with occupational exposure or with exposure to erionite. Core fibres were refractory ceramic fibres in the patient exposed as a grinder in steelworks and erionite fibres in a female exposed in Tuzköy.

Fibre counting by electron microscopy was performed in 40 cases. Tremolite was identified in $75 \%$ of these cases, alone $(n=19 ; 48 \%)$ or together with industrial amphiboles, chrysotile or ceramic fibres $(\mathrm{n}=11 ; 28 \%)$. The mean concentration and range of the different types of asbestos are reported in table 4 . The concentration of tremolite was clearly higher than that of commercial amphiboles in the patients with environmental or mixed exposures. This was also the case for $80 \%$ of the individual counts among those with mixed exposure. Tables 5 and 6 report the number of cases having tremolite or amosite-crocidolite in BALF, according to the likelihood of environmental or occupational exposure.

Distribution of durations of exposure (KolmogorovSmirnov test, $\mathrm{p}<0.01$ ) and delay since end of exposure $(\mathrm{p}<0.001)$ were not similar in immigrants with environmental exposure and current residents of the endemic areas, as half of the current residents of the endemic areas were still exposed when BALF was collected. Comparison of $\mathrm{AB}$ and tremolite fibre

Table 5.-Occurrence of tremolite in bronchoalveolar lavage fluid (BALF) of Turkish immigrants according to geographical origin

\begin{tabular}{|c|c|c|c|}
\hline & \multicolumn{3}{|c|}{ Geographical origin } \\
\hline & $\begin{array}{c}\text { Endemic } \\
\text { area* }\end{array}$ & $\begin{array}{c}\text { Outside } \\
\text { endemic area }\end{array}$ & Unknown \\
\hline $\begin{array}{l}\text { Tremolite present } \\
>300 \text { tremolite } \\
\text { fibres } \cdot \mathrm{mL}^{-1} \mathrm{BALF}^{+}\end{array}$ & $\begin{array}{l}32 / 36(89) \\
16 / 30(53)\end{array}$ & $\begin{array}{l}3 / 8(38) \\
0 / 8(0)\end{array}$ & $\begin{array}{l}4 / 4(100) \\
1 / 2(50)\end{array}$ \\
\hline
\end{tabular}

Data presented as proportions (\%). *: Tremolite and mixed exposure groups; \#: occupational, erionite and unlikely exposure groups; ${ }^{\circ}$ : as asbestos body (AB) core, or in fibre counting using electron microscopy $(\mathrm{EM}) ;^{+}$: eight patients had only AB core analysis (no EM fibre counting). 
Table 6.-Occurrence of commercial amphiboles in bronchoalveolar lavage fluid (BALF) of Turkish immigrants according to the probability of occupational exposure

\begin{tabular}{llll}
\hline & \multicolumn{3}{c}{ Occupational exposure } \\
\cline { 2 - 4 } & Possible* & Unlikely\# & Unknown \\
\hline $\begin{array}{l}\text { Amosite-crocidolite } \\
\text { present }\end{array}$ & $6 / 14(43)$ & $4 / 30(13)$ & $0 / 4(0)$ \\
$\begin{array}{c}\text { More than 300 } \\
\text { Amosite-Crocidolite } \\
\text { fibers } \cdot \mathrm{mL}^{-1} \text { BALF }^{+}\end{array}$ & $2 / 13(15)$ & $0 / 25(0)$ & $0 / 2(0)$ \\
\hline
\end{tabular}

Data presented as proportions (\%). *: Mixed and occupational exposure groups; " : erionite and unlikely exposure groups (all positive cases are males); ${ }^{\uparrow}$ : as asbestos body (AB) core, or in fibre counting using electron microscopy $(\mathrm{EM}) ;^{+}$: eight patients had only $\mathrm{AB}$ core analysis (i.e. no EM fibre counting).

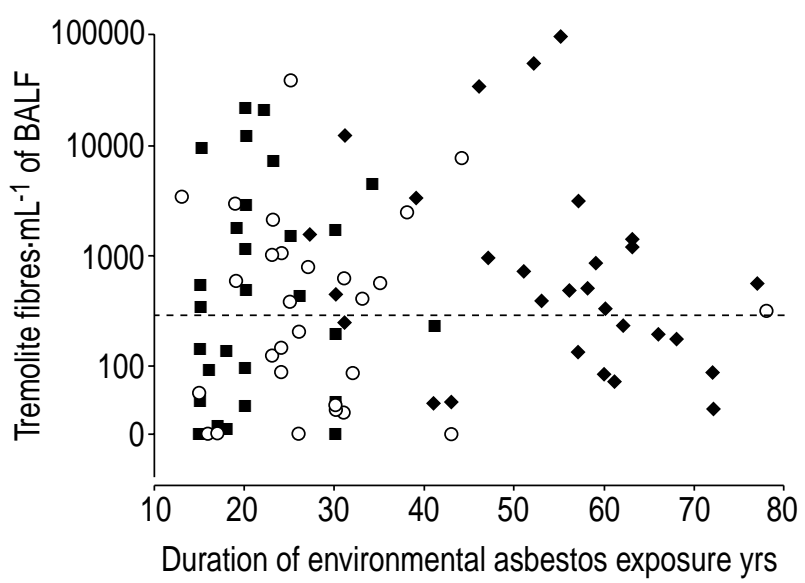

Fig. 1.- Tremolite fibre concentration in bronchoalveolar lavage fluid (BALF) of Turkish immigrants and residents with environmental asbestos exposure according to duration and cessation of exposure [12] shown on a semilogarithmic scale. $\bigcirc$ : Exposed migrants $(n=30)$; $\boldsymbol{\square}$ : residents with cessation of exposure $(\mathrm{n}=30) ;$ : residents with exposure until sampling $(\mathrm{n}=29)$; ----: 300 fibres $\cdot \mathrm{mL}^{-1}$ of BALF.

concentrations in BALF of Turkish immigrants and of residents (fig. 1) failed to show any influence of duration of exposure (Kruskal-Wallis test, $\mathrm{p}=0.27$ ) or delay since end of exposure $(p=0.75)$ on these concentrations.

\section{Discussion}

Past environmental exposure has a major contribution to the total fibre exposure in many Turkish immigrants living in Belgium. Patients and physicians are often unaware of these exposures and may not be able to assess their aetiological role. Tremolite fibres were detected in the BALF of $81 \%$ of all Turkish immigrants while they are very uncommon in lung tissue or BALF of Belgian urban dwellers or workers [14-16].

Tremolite fibres were more frequently observed in Turkish immigrants from areas with environmental exposure $(88 \%)$ than in those from other areas $(38 \%)$. Concentrations exceeding 300 tremolite fibres $\cdot \mathrm{mL}^{-1}$ of BALF are pathognomonic of such environmental exposures.

With appropriate knowledge about exposure conditions in Turkey, the geographical origin can be used as a simple and reliable criterion for environmental exposure [12]. Seventy-five per cent of patients for whom the living place in Turkey was known came from "tremolite areas". Half of them came from the vicinity of Emirdag (a province of Afyon). Approximately a quarter of the Turkish immigrants in Belgium come from this area [17]. This is due to a tendency of inhabitants from one area to immigrate to the same destination. This phenomenon is also well illustrated with the community of Karain villagers living in Sweden [11], while only a few immigrants in Belgium came from the "erionite villages". Accordingly, erionite fibres were rarely detected in the present study.

There were no significant differences in the $A B$ or tremolite fibre concentrations between the BALF of Turkish immigrants and the residents of areas with environmental exposure. The delay since the end of exposure had little influence on the alveolar retention of $A B s$ and tremolite fibres, possibly because of the low clearance of amphiboles. Effectively, it would be an unlikely coincidence that those having left their villages had been more heavily exposed than residents with lifelong exposures and that further clearance lowered their tremolite burden to the same level.

About $20 \%$ of the cases, all males, were found to have possible occupational exposure. Commercial amphiboles were detected in the BALF of $43 \%$ of them, with $>300$ amosite or crocidolite fibres $\cdot \mathrm{mL}^{-1}$ of BALF in two patients. None of those without suspicion of occupational exposure showed such a concentration. It must be noted that the assessment of occupational exposure is based only on the occupation(s) reported by the patient; there was no consideration of duration and intensity of exposure. Moreover, chrysotile fibres were not taken into account in the interpretation of the results of BALF analysis because of the possibility of environmental exposures to chrysotile in some parts of Turkey and the fact that due to a lower biopersistence than that of amphiboles, the chrysotile fibre burden in lung samples is not a reliable marker of exposure [18]. Despite these limitations, an occupational exposure appears very unlikely in a Turkish immigrant when no industrial amphiboles are detected in his BALF (or lung tissue).

All respiratory diseases potentially associated with asbestos fibre inhalation were encountered in this series. Tremolite seems to be the main cause of these diseases. Even for subjects with mixed exposures, tremolite was present in $82 \%$ of those with a fibrerelated disease. The role of environmental exposure must be borne in mind when investigating Turkish immigrants. In addition to BALF, AB and fibre counting, electron microscopy analysis of BALF samples may provide important information on the type of exposure.

Cases of pulmonary fibrosis and mesothelioma were rare as compared to benign pleural diseases. The only case of fibrosis had $1,530 \mathrm{AB} \cdot \mathrm{mL}^{-1}$ of BALF all on 
tremolite fibres. This shows that environmental exposures can be associated with $\mathrm{AB}$ retention in a range compatible with lung fibrosis. In the present authors' experience, about half of the patients with radiological asbestosis due to occupational exposure have $\mathrm{AB}$ burdens higher than $100 \mathrm{AB} \cdot \mathrm{mL}^{-1}$ of BALF [13]. In Turkish immigrants or residents with environmental exposure, such concentrations were observed in $10 \%$ of the cases. This observation is compatible with the rarity of cases of pulmonary fibrosis in this population.

At least one case of lung cancer in the series can be reliably linked with environmental tremolite exposure. This 59-yr-old female had never smoked and had pleural plaques and a pulmonary adenocarcinoma. Histological examination of the resected lung showed no signs of lung fibrosis, but there were 51 million tremolite fibres $\cdot \mathrm{g}^{-1}$ and 1.8 million chrysotile fibres $\cdot \mathrm{g}^{-1}$ of dry lung tissue. Twenty-five per cent of the tremolite fibres were $>5 \mu \mathrm{m}$. This is 10 times the amphibole concentration $\left(5\right.$ million fibres $\left.\cdot \mathrm{g}^{-1}\right)$, which has been estimated to double the risk of lung cancer in occupationally exposed populations [19]. A similar case of lung cancer attributed to environmental tremolite exposure in a 53-yr-old Turkish female with 174 million tremolite fibres $\cdot \mathrm{g}^{-1}$ of dry lung tissue, has been reported previously [3].

The present study was restricted only to cases with known or suspected asbestos related abnormalities. Therefore, the prevalence or incidence of these diseases in the entire population of Turkish immigrants cannot be calculated. The high incidences of asbestos-induced diseases observed in the regions of origin, and data on the number of immigrants, indicate that the public health concern resulting from these exposures is not limited to the population living in the endemic area. Environmental exposures exist in 10 of the 17 Turkish provinces that contributed mostly to the international emigration [20]. According to national statistics, there are about 120,000 Turkish people in Belgium. A representative sociological inquiry performed in 1994/95 among Turkish adult males (1,462 subjects $>19$ yrs old) indicated that $68 \%$ of them had left Turkey after the age of 14 (HMMS inquiry) [17]. Many of them may thus have experienced an important exposure in Turkey before they emigrated. Detailed information about the province of origin and the type of residence (village, small town or large city) are available. It can be concluded that, in Belgium, about 15,400 Turkish immigrants have lived for at least 14 yrs in villages and 6,500 in small towns of the provinces with environmental exposure to tremolite. Due to the number and geographical origin of the Turkish immigrants [20], similar situations may be expected in several other European countries: Germany (2,450,000 Turks), the Netherlands $(350,000$ Turks, with a high proportion coming from Afyon province), France (350,000 Turks) and Sweden $(45,000$ Turks, with a high proportion coming from Konya province).

Compared to the high number of subjects potentially exposed to tremolite among Turkish immigrants, the number of environmental diseases reported is very low. Apart from case reports, there is only a series of 20 cases of mesothelioma among Turkish immigrants from 1987-96, published on the German mesothelioma register [7]. This low reporting rate indicates that the aetiology of many of the individual cases is probably never disclosed. A thorough exposure interview by an experienced person and BALF sampling are useful tools in improving this situation. Another explanation is that the mean age of the immigrants with relevant exposures (in Belgium, $40 \pm 11$ yrs (HMMS inquiry)) is lower than that of the diseased groups in Turkey. For example, pleural calcifications were recorded in $1.7 \%$ of the exposed subjects younger than 40 yrs [2], the mean age of those with plaques in Kureysler village is 51 [21] and the mean age of two series of environmental asbestos-related mesothelioma cases in Turkey were 50 [22] and 56 yrs [23], respectively. A steady increase in the number of environmentally-induced, asbestosrelated diseases could thus be foreseen for the next 20 yrs when the Turkish immigrant population is aging. The feasibility of health surveys among those at the highest risk should be evaluated.

\section{Conclusions}

Pulmonary and pleural asbestos-related diseases resulting from environmental exposure in Central and South-East Anatolia occur in Turkish immigrants originating from these areas. Tremolite is the most frequent fibre in their bronchoalveolar lavage fluid. Asbestos bodies and fibre burdens in lung samples of subjects with environmental exposure to tremolite may be similar to those observed in historical occupational settings. As in endemic areas of Turkey, nonmalignant pleural diseases are the most frequent abnormalities in these patients. A careful interview of the immigrants suspected to originate from countries where endemic asbestos diseases occur should be performed. It must include questions about birthplace (district and village), date of emigration and use of asbestos-containing material. When bronchoalveolar lavage fluid or lung tissue is available, a mineralogical analysis including electron microscopy determination of the fibres should be performed to guarantee that occupational diseases in such immigrants are identified and recognized. An increasing number of cases of asbestos-related diseases are expected in these populations in the near future.

\section{References}

1. Baris Y. Asbestos and erionite related chest diseases. Ankara, Turkey, Semih Ofset Mat Ltd Co.; 1987.

2. Yazicioglu S, Ilcayto R, Balci K, Sayli BS, Yorulmaz B. Pleural calcification, pleural mesotheliomas, and bronchial cancers caused by tremolite dust. Thorax 1980; 35: 564-569.

3. De Vuyst P, Dumortier P, Jacobovitz D, Emri S, Coplu L, Baris YI. Environmental asbestosis complicated by lung cancer. Chest 1994; 105: 1593-1595.

4. Baris YI, Artvinli M, Sahin AA, Bilir N, Kalyoncu F, Sebastien P. Non-occupational asbestos related chest diseases in a small Anatolian village. $\mathrm{Br} J$ Ind Med 1988; 45: 841-842.

5. De Vuyst P, Dumortier P, Gevenois PA. Analysis of 
asbestos bodies in BAL from subjects with particular exposures. Am J Ind Med 1997; 31: 699-704.

6. De Vuyst P, Mairesse M, Gaudichet A, Dumortier P, Jedwab J, Yernault JC. Mineralogical analysis of bronchoalveolar lavage fluid as an aid to diagnosis of "imported" pleural asbestosis. Thorax 1983; 38: 628-629.

7. Fischer M, Brockman S, Gunther S, Muller KH. Pleuramesotheliome bei Turkishen Patienten. Kompass 1996; 106: 171-176.

8. Schneider J, Rodelsperger K, Bruckel B, Kayser K, Woitowitz HJ. Environmental exposure to tremolite asbestos: pleural mesothelioma in two Turkish workers in Germany. Rev Environ Health 1998; 13: 213-220.

9. Magee F, Wright JL, Chan N, Lawson L, Churg A. Malignant mesothelioma caused by childhood exposure to long-fibre low aspect ratio tremolite. $\mathrm{Am} \mathrm{J}$ Ind Med 1986; 9: 529-533.

10. Voisin C, Marin I, Brochard P, Pairon JC. Environmental airborne tremolite asbestos pollution and pleural plaques in Afghanistan. Chest 1994; 106: 974-976.

11. Metintas M, Hillerdal G, Metintas S. Malignant mesothelioma due to environmental exposure to erionite: follow-up of a Turkish emigrant cohort. Eur Respir J 1999; 13: 523-526.

12. Dumortier P, Coplu L, de Maertelaer V, Emri S, Baris I, De Vuyst P. Assessment of environmental asbestos exposure in Turkey by bronchoalveolar lavage. Am J Respir Crit Care Med 1998; 158: 1815-1824.

13. De Vuyst P, Dumortier P, Moulin E, Yourassowsky N, Yernault J. Diagnostic value of asbestos bodies in bronchoalveolar lavage fluid. Am Rev Respir Dis 1987; 136: 1219-1224.

14. Moulin E, Yourassowsky N, Dumortier P, De Vuyst P, Yernault JC. Electron microscopy analysis of asbestos body cores from the Belgian urban population. Eur Respir J 1988; 1: 818-822.

15. Dumortier P, De Vuyst P, Strauss P, Yernault JC. Asbestos bodies in bronchoalveolar lavage fluids of brake lining and asbestos cement workers. $\mathrm{Br} J$ Ind Med 1990; 47: 91-98.

16. De Vuyst P, Dumortier P, Leophonte P, Vande Weyer R, Yernault JC. Mineralogical analysis of bronchoalveolar lavage in talc pneumoconiosis. Eur J Respir Dis 1987; 70: 150-156.

17. Manco A, ed. Sociographie de la population turque et d'origine turque. Quarante ans de presence en Belgique [1960-2000]. Dynamiques, problematiques, perspectives. Bruxelles: Centre des Relations Europeennes 2000; pp. 237.

18. De Vuyst $\mathrm{P}$, Karjalainen A, Dumortier $\mathrm{P}$, et al. Guidelines for mineral fibre analyses in biological samples: report of the ERS Working group. Eur Respir J 1998; 11: 1416-1426.

19. Anonymous. Asbestos, asbestosis, and cancer: the Helsinki criteria for diagnosis and attribution. Scand J Work Environ Health 1997; 23: 311-316.

20. De Tapia S, ed. Turcs d'Europe...et d'ailleurs. Les annales de l'autre Islam, no.3. Paris: INALCO/ CNRS/ERISM 1995; pp. 535.

21. Coplu L, Dumortier P, Demir AU, et al. An epidemiological study in an Anatolian village in Turkey environmentally exposed to tremolite asbestos. J Environ Pathol Toxicol Oncol 1996; 15: 177-182.

22. Selcuk ZT, Coplu L, Emri S, Kalyoncu AF, Sahin AA, Baris YI. Malignant pleural mesothelioma due to environmental mineral fibre exposure in Turkey. Analysis of 135 cases. Chest 1992; 102: 790-796.

23. Metintas M, Ozdemir N, Hillerdal G, et al. Environmental asbestos exposure and malignant pleural mesothelioma. Respir Med 1999; 93: 349-355. 